\title{
STUDENTS’ ATTITUDES TOWARD IMPLEMENTATION OF PROJECT BASED LEARNING
}

\author{
Yanuarti Apsari ${ }^{1}$, Euis Rina Mulyani ${ }^{2,}$ Ida Lisdawati $^{3}$ \\ 1,2,3 IKIP Siliwangi \\ ${ }^{1}$ yanuar.apsari1@gmail.com, ${ }^{2}$ euisrinamulyani@gmail.com, ${ }^{3}$ idalisdawati9088@ gmail.com
}

\begin{abstract}
This research is intended to investigate the students' attitudes toward the implementation of projectbased learning. Project based learning is becoming increasingly popular in the pedagogical field. Qualitative research method was employed in this study. The respondents of this study were the fourth grade students who were taking coursebook evaluation subject. The data of this study was gathered by using questionnaire. Then, the collected data were analysed by qualitative description. Based on the questionnaire data, the result indicates that the respondents have a positive attitude towards the implementation of project based learning. It can be seen from three aspects: affective, behavioral, and cognitive aspects. On affective aspect, the respondents were interested to learn by using project based learning because of several benefits that they get after learning by using project based learning. In addition, on cognitive aspects, the findings showed that all respondents believe that project based learning is effective in teaching coursebok evaluation subject. The last, on the behavior aspect, the data showed that during the implementation of project based learning the respondents likes to share ideas and discuss in their group.
\end{abstract}

Keywords: Project-based Learning, Students' attitudes, Coursebook Evaluation

\begin{abstract}
Abstrak
Penelitian ini bertujuan untuk menyelidiki sikap siswa terhadap terhadap pembelajaran berbasis proyek. Metode kualitatif digunakan dalam penelitian ini. Responden dari penelitian ini adalah mahasiswa semester empat yang sedang mengambil mata kuliah coursebook evaluation. Kemudian, data yang dikumpulkan dianalisis dengan deskripsi kualitatif. Berdasarkan data kuesioner, hasilnya menunjukkan bahwa responden memiliki sikap positif terhadap pelaksanaan pembelajaran berbasis proyek. Itu bisa dilihat dari tiga aspek: aspek afektif, perilaku, dan kognitif. Pada aspek afektif, responden tertarik untuk belajar dengan menggunakan pembelajaran berbasis proyek karena beberapa manfaat yang mereka dapatkan setelah belajar dengan menggunakan pembelajaran berbasis proyek. Selain itu, pada aspek kognitif, temuan menunjukkan bahwa semua responden percaya bahwa pembelajaran berbasis proyek efektif dalam mengajar mata pelajaran evaluasi coursebok. Terakhir, pada aspek perilaku, data menunjukkan bahwa selama pelaksanaan pembelajaran berbasis proyek, responden suka berbagi ide dan berdiskusi dalam kelompok mereka.
\end{abstract}

Kata Kunci: Mata kuliah coursebook evaluation , Pembelajaran berbasis proyek, sikap siswa

How to Cite: Apsari, Y., Mulyani, E. R., \& Lisdawati, I. (2019). Students' Attitudes Toward Implementation Of Project Based Learning. JEE, 2 (2), 123-128. 


\section{INTRODUCTION}

Teaching strategy is a means that teacher chose and used for delivering learning material. It is intented to ease students to accept and understand it so that they can get goal of learning in the end of learning process. One strategy that can implemented by teacher is Project-based Learning (PBL). According to Bell (2010), 21st Century skills are commonly associated with project-based learning. Project-based learning is an authentic learning model or strategy in which students plan, implement, and evaluate projects that have real-world applications beyond the classroom (Westwood, 2008). In general, project-based learning is divided into three stages namely planning, implementing, and presenting. During the implementation of project based learning, students explore, evaluate, interpret, synthesize, and convey information. Thus, project-based instruction implementation fosters critical thinking (Savery, 2006).

Some previous studies show some positive outcome from Project-Based Learning. According to Legutke (1993), projects are considered to motivate learners and increase their interests in learning. Moreover, Project-Based Learning aims to engage students in the investigation of real life phenomena and develop students' creativity (Becket and Miller, 2006). Furthermore, Williams (2017) adds that Project based learning give students the opportunity to get involved in learning and learn new soft skills such as collaboration, communication and negotiation. Moreover, Neo \& Neo (2009) argue that PBL has been enhanced the studentse interest, critical thinking abilities, presentation skills, communicative skills and the ability to work on a team.

\section{Attitude}

Stark et al (2013) argue that attitude is "tendency to respond positively or negatively towards a certain thing such as an idea, object, person, or situation". According to Abidin et al (2012), there are two kinds of language attitude in language learning, they are positive attitudes and negatives attitude. Positive and negative attitudes can influence the language learning; the person who holds strong beliefs in positively valued outcomes will result positive attitude (Montano \& Kasprzyk, 2008).

(Brown, 1994) proposed the three components of the attitude. They are affective, behavioral / conative, and cognitive. Affective refers to a person's feelings or emotions about the attitude object, such as "like", "dislike", "with", or "against". While, behavioral/conative refers the way the attitude that we have, could influence how we act or behave. Cognitive refers expressions of beliefs and ideas or opinions about the object of the attitude.

Based on the description above, this study is intended to investigate the students' attitude toward the implementation of project based learning in coursebook evaluation classroom.

\section{METHOD}

This study is limited to one private university in Cimahi, Indonesia. It shows students' attitudes toward implementation of project based learning in coursebook evaluation. Respondents in this study fourth semester students of English education study program. In this study, reserachers used survey questionnaires. Questionnaire survey is one of the most common methods of data collection on attitudes and opinion from large group of participants ( Mackey \& Gass 2005, cited in Ahmed, 2015). 
The survey questionnaire consisted of 10 statements that consists of 5- level Likert scale for finding their agreement level with $5=$ strongly agreement, $4=$ agreement, $3=$ normal. $2=$ disagree and $1=$ strong disagree. They were asked to fill out 15 questions. It consisted of three sections: affective, behavioral, and cognitive. The first five questions focused on students activities in the classroom. It explained students feeling related to learning method that the lecturer used in the classroom and their feeling related to assigment that the lecturer gave to them The second five qustions focused on students' belief related to learning progress used project based learning, and the last five questions focused on students' action after following Coursebook Evaluation subject using project based learning. After collecting data result, data classified based on the catagories explaining three student's responses based on Likert scale and described result used descriptive explanantion.

\section{RESULTS AND DISCUSSION}

\section{Results}

The result of data analysis revealed three aspect of students' attitude towards the implementation of project based learning in coursebook evaluation class. The findings related to affective, behavioral and cognitive as presented in the followings tables.

Table 1.Students' Result Questionnaire

\begin{tabular}{|c|c|c|c|c|c|c|}
\hline No & Statement & $\begin{array}{l}\text { Strong } \\
\text { agree }\end{array}$ & agree & Neutral & disagree & $\begin{array}{c}\text { Strong } \\
\text { disagree }\end{array}$ \\
\hline 1 & $\begin{array}{l}\text { Students are more interested to } \\
\text { learn by using project based } \\
\text { learning than tranditional teaching }\end{array}$ & $\begin{array}{l}58.53 \% \\
(24)\end{array}$ & $\begin{array}{l}33,33 \% \\
(14)\end{array}$ & $\begin{array}{l}4.87 \% \\
(2)\end{array}$ & $\begin{array}{l}2,43 \% \\
(1)\end{array}$ & - \\
\hline 2 & $\begin{array}{l}\text { New and challenge experience will } \\
\text { create students' knowledge }\end{array}$ & $\begin{array}{l}53,65 \% \\
(25)\end{array}$ & $\begin{array}{l}34.14 \% \\
(14)\end{array}$ & $\begin{array}{l}4.87 \% \\
(2)\end{array}$ & - & - \\
\hline 3 & $\begin{array}{l}\text { Project based learning increased } \\
\text { students' critical thinking level }\end{array}$ & $\begin{array}{l}51.21 \% \\
(21)\end{array}$ & $\begin{array}{l}29.02 \% \\
16\end{array}$ & $\begin{array}{l}4.87 \% \\
(2)\end{array}$ & - & - \\
\hline 4 & $\begin{array}{l}\text { Students became more creative } \\
\text { when they do their project because } \\
\text { it needs many steps }\end{array}$ & $\begin{array}{l}48.78 \% \\
(20)\end{array}$ & $\begin{array}{l}36.58 \% \\
(15)\end{array}$ & $\begin{array}{l}7.31 \% \\
(3)\end{array}$ & $\begin{array}{l}7.31 \% \\
(3)\end{array}$ & - \\
\hline 5 & $\begin{array}{l}\text { Project based learning increased } \\
\text { team work ability }\end{array}$ & $\begin{array}{l}60.97 \% \\
(25)\end{array}$ & $\begin{array}{l}34.14 \% \\
(14)\end{array}$ & $\begin{array}{l}2.43 \% \\
(1)\end{array}$ & $\begin{array}{l}2.43 \% \\
(1)\end{array}$ & - \\
\hline 6 & $\begin{array}{l}\text { Doing the project requires read a } \\
\text { lot }\end{array}$ & $\begin{array}{l}41.46 \% \\
(17)\end{array}$ & $\begin{array}{l}34.14 \% \\
(14)\end{array}$ & $\begin{array}{l}9.75 \% \\
(4)\end{array}$ & $\begin{array}{l}12.19 \% \\
(5)\end{array}$ & $\begin{array}{l}2.43 \% \\
(1)\end{array}$ \\
\hline 7 & $\begin{array}{l}\text { Project based learning is effective } \\
\text { in teaching coursebook evaluation }\end{array}$ & $\begin{array}{l}100 \% \\
(31)\end{array}$ & - & - & - & - \\
\hline 8 & $\begin{array}{l}\text { The goal of project depends on } \\
\text { students }\end{array}$ & $\begin{array}{l}39.02 \% \\
(16)\end{array}$ & $\begin{array}{l}46.34 \% \\
(19)\end{array}$ & $\begin{array}{l}7.31 \% \\
(3)\end{array}$ & $\begin{array}{l}7.31 \% \\
(3)\end{array}$ & - \\
\hline 9 & $\begin{array}{l}\text { In creating the project, the students } \\
\text { often share their ideas }\end{array}$ & $\begin{array}{l}48.78 \% \\
(20)\end{array}$ & $\begin{array}{l}48.78 \% \\
(20)\end{array}$ & $\begin{array}{l}2.43 \% \\
(1)\end{array}$ & - & - \\
\hline 10 & $\begin{array}{l}\text { In the implemetation project-based } \\
\text { learning in coursebook evaluation } \\
\text { subject, students like to discuss in } \\
\text { their group }\end{array}$ & $\begin{array}{l}36.58 \% \\
(15)\end{array}$ & $\begin{array}{l}31.70 \% \\
(13)\end{array}$ & $\begin{array}{l}17.07 \% \\
(7)\end{array}$ & $\begin{array}{l}14.63 \% \\
(6)\end{array}$ & - \\
\hline
\end{tabular}




\section{Discussion}

The findings in Table 1 showed that the majority of the respondents showed their positive attitude on the affective aspect (58.53\%). They said that they are more interested to learn by using project based learning than tranditional teaching. This indicates that they strongly agree that learning strategy was an important factor influenced them to felt interested in learning process in the classroom. In other words, projects do create learners' enjoyment in learning coursebook evaluation subject. This is in line with the statement of Legutke (1993) that projects are considered to motivate learners and increase their interests in learning.

In addition, refferring to the cognitive aspect, the statement number 2 revealed that most of the respondents strongly agree that in the learning process and giving a task by the teacher would increase their knowledge (53.63\%). It is relevant with the statement of William (2017) that Project based learning give students the opportunity to get involved in learning and learn new soft skills such as collaboration, communication and negotiation. Furthermore, over 20 respondents $(51.21 \%)$ strongly agreed that project based learning increased students' critical thinking. As Savery's (2006) studies indicate that project-based instruction implementation fosters critical thinking.

Furthermore, the data also revealed that statement number 4 and 5 were set for find response related to implementation of project in the classroom. 20 respondents (48.78\%) strongly agreed that when students did their project, they became more creative. 15 students $(36.58 \%)$ said that they were creative enough when they had to finish their project because it had several steps before accomplishing it. It is in line with the statement of Beckett\&Miller (2006) that Project-Based Learning aims to engage students in the investigation of real life phenomena and develop students' creativity.

Another point was showed in the statement number 6. 25 students $(60.97 \%)$ strongly agreed to when the the teacher gave them project as grouping task in the classroom, it would increase their team work ability. Apart of that, 14 students (34.14\%) agreed that project given by their teacher increased their team work. Regardless of both of statements above, 1 student $(2.43 \%)$ was not aware that project task could increase team work ability. This indicates that Project Based Learning has enhanced students' ability to work on a team.

Finally, the statement number 7 showed that All respondents (100\%) agreed that Project based learning is effective in teaching coursebook evaluation

Relating to the behavioral aspect, statement number 10 to 14 showed that there were several activities that the students did in project-based learning strategy. 20 respondents $(48.78 \%)$ agreed that in creating the project, the students often share their ideas. 15 respondents $(36.58 \%)$ likes to discuss with their group and they were trained to find a solution. This means that, the students are responsible to collect information, analyze and interpret data, and present them as the outcome of their learning (Simpson, 2011).

\section{CONCLUSION}

This study investigates students' attitude toward the implementation of project based learning in coursebook evaluation class. Based on the questionnaire data, many respondents had positive attitudes toward the impelementation of project based learningIt can be seen from three aspects; affective, behavioral, and cognitive aspects. 
On the affective aspect, many participants showed their positive attitudes (58.53). They were interested to lealrn by using project based learning because of several benefits that they get after learning by using project based learning. In addition, on cognitive aspects, the findings showed that All respondents believe that project based learning is effective in teaching coursebok evaluation subject. In addition, the respondents also said that project based learning help the students to improve their knowledge, critical thinking and creativity. While, on the behavior aspect, the data showed the reason of students enjoyed during the implementation of project based learning. It was due to the several activities employed in this study. As stated by 20 respondents $(48.78 \%)$ that in creating the project, the students often share their ideas and 15 respondents $(36.58 \%)$ likes to discuss with their group and they were trained to find a solution.

\section{ACKNOWLEDGMENTS}

The highest gratitude to Allah SWT for opportunity and blessing us, so we can complete this article. We thank the beloved campus IKIP SILIWANGI Bandung as our institution who gave as fund to conduct the research.

\section{REFERENCES}

Abidin Dr., M. J. Z., Pour-Mohammadi, M., \& Alzwari, H. (2012). EFL students' attitudes towards learning English language: The case of Libyan secondary school students. Asian Social Science. https://doi.org/10.5539/ass.v8n2p119

Ahmed, S. (2015). Attitudes towards English Language Learning among EFL Learners at UMSKAL. Journal of Education and Practice.

Becket, G and Miller, P. (2006). Project-Based Second and Foreign Language Education: Past, Present, and Future (Research in Second Language Learning.

Bell, S. (2010). Project-Based Learning for the 21st Century: Skills for the Future. The Clearing House: A Journal of Educational Strategies, Issues and Ideas, 83(2), 39-43. https://doi.org/10.1080/00098650903505415

Brown, H. (1994). No Title. New York: Prentice Hall Regence.

Legutke, M. (1993). Room to talk: Experiential learning in the foreign language classroom, Die Neueren Sprachen. 92(4), 306-331.

Montano, D. E., \& Kasprzyk, D. (2008). The Theory of Reasoned Action, Theory of Planned Behavior and The Integrated Behavioral Model. In Health Behavior and Health Education: Theory, Research, and Practice.

Neo, M \& Neo, T. (2009). Engaging students in multimedia-mediated constructivist learning-Students' perceptions. Educational technology \& Society. Educational Technology \& Society, 12(20), 254- 66.

Savery, J. R. (2006). Overview of problem-based learning : Definitions and distinctions origins of PBL. Interdisciplinary Journal of Problem-Based Learning, 1(1), 9-20. Retrieved from http://citeseerx.ist.psu.edu/viewdoc/summary?doi=10.1.1.470.2497

Simpson, J. (2011). Integrating project-based learning in an English language tourism classroom in a Thai university institution.

Stark, T. , Flache, A., \& V. (2013). Generalization of positive and negative attitudes toward individuals to outgroup attitudes.

Williams, S. (2017). Investigating the allocation and corroboration of individual grades for project-based learning. Studies in Educational Evaluation, 53(February), 1-9. https://doi.org/10.1016/j.stueduc.2016.10.009 
128 Apsari, Mulyani \& Lisdawati, Students' Attitudes Toward Implementation Of... 